\title{
Verbal and nonverbal language in EFL classrooms
}

\section{Lílian Maria Dantas}

Professora da Universidade Estadual de Alagoas e mestre pelo PPGLL/UFAL.

\section{Roseanne Rocha Tavares}

Professora do curso de Letras da Fale/UFAL, atua no Programa de Pós-graduação em Letrase Lingüistica da FALEJUFAL, na linha de pesquisa aquisiçāo da linguagem e ensino e aprendizagem de línguas. É lider do grupo de pesquisa Prática Interativas do discurso em contextos institucionais.

Abstract: The main objective of this paper is to show some results from a research that focused on the influence of nonverbal language (together with verbal) in EFL classroom interaction. The methodological approach chosen to execute it had an ethnographic focus, based on Erickson's (1996) ethnographic micro-analysis of interaction. The focus of our investigation turned out to be the smile. The three types of smile noticed contributed to lower the affective filter, increase interaction and consequently improve students' learning.

Palavras-chave:interação em sala de aula de língua estrangeira; linguagem verbal e não verbal; o sorriso
Resumo: O objetivo principal deste artigo é apresentar resultados de uma pesquisa que analisou a influência da linguagem não verbal (juntamente com a verbal) na interação de sala de aula de Língua Inglesa como língua estrangeira. Entre os muitos tipos de linguagem não verbal, 0 foco da nossa investigação foi o sorriso. Os tipos de sorriso observados contribuíram para diminuir o filtro afetivo entre o professor e os alunos, aumentando a interaçāo e, conseqüentemente, a produção e aprendizado dos mesmos.

Key words: interaction in foreign language classroom; verbal and nonverbal language; the smile 



\section{Introduction}

Nowadays, learning a foreign language is seen as an experience which involves both the learner and the teacher interactively and reflects the social-cultural aspects and values of a particular community or country. Language is a social activity which cannot be studied separately from interaction, from its social context and its historical reality (TAVARES, 2001; ORLANDI, 2005). Within this view of language, Kramsch (1993), who works in the area of Foreign Language Teaching and Applied Linguistics, argues that language expresses cultural reality (world knowledge shared by people through ideas, facts or events); it embodies cultural reality (people who belong to the same group, make use of language as the medium to communicate); and language symbolizes cultural reality because "speakers view their language as a symbol of their social identity" (p.313). The author also mentions other view of culture:

But there is another way of viewing culture - one which takes a more historical perspective. The culture of everyday practices draws on the culture of shared history and traditions. People identify themselves as members of a society to the extent that they can have a place in that society's history and that they can identify with the way it remembers its past, turns its attention to the present, and anticipates its future (p.7).

This alternative way of viewing culture is what makes people aware of their role in society, as members of a community and as ones who can identify themselves with that community. In instructional settings such as the classroom, this view becomes a little distant as the learners are not learning their own language, but a foreign language. The teacher then has an important role which is to be able to link culture and language in order to provide a more complete learning experience, having them use the language and understand it in different contexts of everyday life. 
Even though there have been great advances concerning the teaching of a foreign language at public schools, our country still has followers of the traditional method (based on grammar and translation). The teacher's concept of foreign language, his/her teaching approach/ method, institutional factors, the material used to teach and the community's learning and teaching tradition will help to determine how and why the foreign language is being taught and learned the way it is in any specific classroom. Almeida Filho (1993) perfectly defines his idea of an approach to teaching and learning a foreign language. He says that learning a foreign language involves affection such as feeling motivated, knowing that one can take risks to be able to speak the new language, lower anxiety and group pressure. This research concentrates on the use of nonverbal language, more specifically the smile, and its reflect on a language learning environment as well as the relation between teacher-students, concerning classroom interaction and the feelings and emotions mentioned by the author above.

It is common knowledge that secondary schools in our country do not really make a connection between what is being taught and the learners' own experiences. As we have mentioned before, most schools still treat the teaching of a foreign language as a traditional and mechanical one, making use of translations and very little oral practice resulting in meaningless learning as described above.

This is due to several reasons such as the teachers' lack of experience and language background, lack of extra materials to work with, equipment, creativity, among other reasons already mentioned.

This research was conducted at the extension school of the Federal University of Alagoas, which according to data collection and classroom observation, shares the same concept of teaching and learning a foreign language as the one described by Almeida Filho (1993). In order to obtain the corpus, a number of twelve classes which lasted two hours and ten minutes each were 
observed, selected and transcribed later on. It started in August, 2005 and it lasted the whole semester. We took field notes of ten classes and recorded six entire classes. Students had classes only on Fridays which meant that each recorded lesson was equivalent to two regular classes a week at that school. There were usually about 8 or 10 students present and they were having preparatory classes for the FCE (First Certificate in English).

In Brazil, there is important research which relate classroom interaction and the use of nonverbal language (such as research done by TAVARES, 2001; SANTOS, 2004 and others) although we have found no research which specifically relates and analyzes the influence of nonverbal language to the learning of a foreign language and its importance.

In order to reflect about the nature of nonverbal and verbal language in EFL classrooms, this research is also concerned about observing the teaching and learning process of a foreign language. As Almeida Filho (1993) says, students bring into the learning non-natural environment all their expectations about what it is like to learn another language, their anxiety and tolerance towards the target language, their motivation, their limitations which are called affective filters. Learning a foreign language, according to the same author, means providing relevant, meaningful, valid and deep experiences that will consequently result in growing interactive moments in the target language. We intend, with this work, to investigate how nonverbal language can (together with verbal) influence EFL classroom interaction?

In order to understand the interactional process which occurs between teacher and learners in a classroom, it is important to understand that such a process is part of a macro context in which the elements are interrelated and influence one another. Therefore, to understand the use of verbal and nonverbal language in EFL classrooms, it is necessary to highlight what interaction really is in this language learning environment. 
The pioneers from the Anglo-Saxon DA trend in studying and writing about classroom interaction were Sinclair and Coulthard (1975). To them, typical classroom interaction consists of a sequence of cycles which they call interchanges and each one is composed of three moments known as IRF (initiation-response-feedback), or as IRE (initiation-response-evaluation) by Mehan (1978), where the teacher initiates the interaction by means of a question for example, the student will response to this question and the teacher will evaluate the student's response.

In Brazil, Leffa $(2003,2005)$ developed studies about classroom interaction in language learning and also about interaction in the virtual world. Leffa comments on the authors' interactive model (IRF) saying that it seems to characterize the expositive-dialogued type of classroom from the last decades and also a tendency in recent classes where the initiative of each cycle always comes from the teacher. Although the teacher maintains a dialogue with the students, he/she still exerts a central role as the class interaction conductor.

To Rivers (1987), interaction occurs when pupils are able to convey and receive messages which are of interest for the listener and the speaker in a context which is also relevant for both. According to Wells (1981, p.29, 46-7 apud RIVERS, 1987, p. 4) "exchange is the basic unit of discourse [...] Linguistic interaction is a collaborative activity involving the establishment of a triangular relationship between the sender, the receiver and the context of the situation". The author believes it is important, according to her own experience when learning a foreign language, that the teacher shows interest in teaching, be active, imaginative and innovative, developing a rapport with the students which will help them feel involved and motivated. Interaction also involves understanding others' ideas, listening and responding to others, working out interpretations of meaning, all related to a context which can be physical or experimental, and having the help of nonverbal language over the verbal. 


\section{Defining Nonverbal Language}

When interaction is observed and analyzed, not only verbal language is usually activated but there is also the influence of nonverbal language. The authors Rector \& Trinta (1999, p.21) add that "verbal and nonverbal are two modalities of exercise of the human language faculty, through the linguistic expression, in the first case, and through significant body movement, in the second" (p.21).

In Rector \& Trinta's view (1985), the nonverbal resources used by speakers in any type of social interaction, being responsible for the majority of the exchanged information, are represented by:

a) paralanguage, that is any type of nonverbal communicative activity that accompanies verbal behavior during a conversation. Examples of paralanguage are increasing and decreasing intonations, pauses like "humm", a smile, a look.

b) The Kinesics is a subject which studies body movements and gestures, postures and facial expressions. The studies about kinesics were initiated in 1952, by R. Birdwhistell. That was when a series of systematic researches about body movements started, regarding it as a science that is worried about the communicative aspects of learned and structured behavior of the body when moving.

c) The study about the use of space is called proxemics; and the use of time, chronemics.

d) The taxesic is the use of the touch in human interaction; and the silence is explained by the absence of linguistic constructions brought from paralanguage (STEINBERG, 1988, apud RECTOR \& TRINTA, 1999). The categories above act in every form of communication as well as the ones which integrate human behavior.

In order to read the discursive interactions which happen in the classroom, it is important to consider the allusive aspects related to time and space. There are two different ways in which one can relate to time: the monochronic and the polichronic. The first is typical of people who do one thing at a time and the second is true for people who do several activities simultaneously (SANTOS, 2004). 
This research concentrates on the polichronic type as the teacher observed clearly conducted more than one activity at a time (like talking, lifting an arm and smiling) but making sure she was being understood and the subject was being learned in order to move to another step.

When it comes to distance, Santos (2004) mentions four types as follows:

1. intimate distance the physical involvement between two participants, justified by the proximity and the body contact;

2. personal distance a certain intimacy or formality in social events;

3. social distance: typical in commercial transactions of meetings with important people;

4. public distance. seen as those which happen in public speeches and conferences for the fact that the language spoken is more formal and the voice is paused and slower.

The context in which this research happened showed a personal type of distance which sometimes varied from a little informal in order to promote better interaction to a little formal, in order to define the roles in the classroom (the latter occurred whenever the teacher was supposed to remind students of their role as learners). Verbal and nonverbal languages cannot be studied separately. Understanding verbal interaction will help analyze the influence of nonverbal language (such as gestures, facial expressions, body movements and others) to the learning of a foreign language and at which moments of verbal interaction the nonverbal was mostly predominant and why.

\section{The Smile}

People interact with everything which is in the universe like other people, objects and others. "We are always acting and reacting with the context surrounding us" (LEFFA, 2003, p.2). In the learning environment it is not different, teachers and learners, learners and learners, the whole group, learners and textbook etc, there is 
constant interaction going on. In order to understand the interactive process in a foreign language class, it is important to analyze both verbal and nonverbal language together because as it has been mentioned, they are part of a continuum and cannot be studied separately. Among the different types of nonverbal language present throughout data collection and observations, the one which called more attention and was more significant in the learning process was the smile.

According to a study conducted by FreitasMagalhães (2004), a Portuguese psychologist, there are three types of smile: 1 . a wide smile - when we smile and see the teeth; 2 . a superior smile - when just the superior teeth are seen and 3 . the closed smile - when the teeth are not seen and the person's face does not change much. According to the researcher, people that smile with the lips closed, without showing their teeth are seen by others as affectionate. Among the other types, the closed smile besides showing affection, it is also a smile of seduction. Between men and women, the latter are seen as being more affectionate than men as they use the closed smile much more often. Women also smile more socially than men in an attempt to please others. It is almost involuntary, but more seductive and true (the smile is suggestive). Other comments have been written about the smile:

* The smile is contagious (and also suggestive) (PEASE and PEASE, 2005).

*Smiling makes anyone enter the "happy zone" in the brain which makes one feel spontaneous happiness (CARVALHO, 1999).

"A smile is the number one feature that makes people attractive. It's a welcome mat. It's what makes folks approachable (KINDE ,1999).

" say that smiling and laughing can both contribute to a person's general well-being. When incorporated to our personality, it attracts friends, improves the health and extends life (PEASE and PEASE , 2005). 


\section{The smile in a foreign language teaching class: the three different types}

Throughout the research, we observed three different ways in which the smile was used by the teacher in the classroom in order to promote a convivial strategy. One of them was making use of the smile to reprimand students for not coping with what had been agreed before (such as doing homework, buying the book etc). This procedure is clear in the following example:

Interactive Moment (IM) 1 - Class 5 - Type of smile = reprimand

IM1

((It is time to start the class. T enters the classroom smiling))

1 T: so, how was your holiday? ((some students move hands as if saying "not bad")) what did you do?

SI: studied.

T: studied? ((she looks at another student)) studied too?

S2: ((nods head positively))

$5 \mathrm{~T}$ : and you alberto? what did you do?

Alberto: studied.

$T$ : everybody studied this holiday?

Alberto: I did a test XXX.

$\mathrm{T}: \mathrm{u} \ldots \ldots \mathrm{h}$ right! $\mathrm{a} \ldots \mathrm{nd}, \mathrm{u} \ldots \ldots \mathrm{h}$, did you study english too?

10 Alberto: no.

((T smiles, places hands on the waist and nods head from left to right $)$ ) naughty, naughty students. a :..nd, but... have... do you.... have you done any homework? have you done the homework?

((a student comes in))

T: o......h, rachel! XXXX. so, have you done the homework in the exam... uh...exam maximizer? ((she smiles

15 with both hands on the waist)).

('students are silent))

$\mathrm{T}$ : how do you think ... you're going to pass the exam? ((smiling)) tell me!! ((she places hands on the waist)) ('students are silent))

$\mathrm{T}$ : be sincere!

20 alberto: XXX

('some students laugh))

$\mathrm{T}$ : in ten years' timel ((smiling))

alberto: ten years?

$\Gamma$ : yeah? people... the fact that you're coming once a week doesn't mean you don't have to studyl this is, this

25 is just part of the process! you have... lots of things to do at home!

S2: XXX

$\mathrm{r}$ : two hours and a half less than that per week! yeah? so, if you don't make the most... of the material, of your time... preparing for the exam, l'm sorry but you won't pass.

$30 / \ldots 1$

I: right? because I' $m$ talking about the homework because I suppose that AT THIS LEVEL, with A GROUP LIKE THAT, I don't think... I'm supposed to CHECK homework . to check if you're doing or not. ((she smiles)). this is something that YOU have to do .... without the teacher's pressure.

35

$1 . .1$

T: I would do it today, but as just two students have the book ((smiling)), so I'm going to do next class, ok? OK. so, agreed on that?((she smiles)) so, let's .. so ... BE.... honest to yourselves, see the things you have to 40 to ... and then if you don't pass the exam, don't blame the teacher, yeah? ((T smiles again)) 
According to the teacher, she smiled whenever she wanted to reprimand students due to the fact that she did not want to threaten them, sound unfriendly and create an unpleasant learning environment, afterwards. Although she smiled, students felt they were being reprimanded and responded with silence. The silence then indicated that the message was received and they accepted without speaking because the teacher was right. They were not doing their duties which involved doing homework, extra tasks and others. The fact that they did not do what they were supposed to annoyed her but this feeling was disguised with a smile.

Another interesting aspect about the use of the smile in the language classroom was to promote a convivial strategy (teacher - students). The teacher made it an instrument in order to increase interaction between her and the students, which resulted in students' active participation (Interactive moment 3 ). They felt like talking, like giving their opinion and showing their points of view. It worked so well that there were times in which the teacher had to break the flow of the conversation in order to go on with her lesson plan. Some aspects are shown below (interactive moment 4).

The class begins with the teacher reminding the students about the speaking paper in the exam (FCE). By asking questions, she revises some common topics in the exam like free time activities and personal questions. She then plays a game which practices the two topics. Before working with the book, she does a quiz with the students. 


\section{Interactive Moments 3 and 4-Class 4-type= convivial strategy \\ IM3}

1 (In order to introduce the topic about free time actuvities and adventure as well as dangerous sports, the teacher uses a transparency with a personality test which indicates, in the end, how adventurous the personis)

[..]

5 T: so, do you agree with the results?

S1: no.

T' no? you thınk you are more or less? than that?

Si less.

T: less? not so wild, yeah? and you? ((and looks at another student, smiling))

10 S2: yes not tha $t$ much (( $\mathrm{T}$ smiles))

T: maybe you are not conscious about how wild you are, uh? so, would you like to try extreme sports? risky sports?

S3: yeah!

T: yeah? so, what sports?

I5 S3 l'd like to go climbing

$\mathrm{T}$ : what about the others?

S4: (XXX) ((students laugh))

$\Gamma$ no? so, describe it

S4: I don't know how to describe it

20 (( T smiles ))

S5 chess?

((several students laughi))

SG: Ilike to skate skating and those those uh

S3 snowboard?

2556 it's not snowboard... skating and those (XXX). how do you say "rampa"?

T: slope?

S6: slope? (XXX)

T: uhm.

S3: it's a "raf".

30 S6: "raf"?

33. yes we call "raf"

T: yeah

56. 1 can't remember $(\mathrm{XXX})$

T: I don't know that but anyway, it's a ... you need a skateboard?

35 S6: yeah

$\mathrm{T}$ ah! all right. ok. so, open your books. something really extreme is on page 18. yeah look in your books no book? (( T smiles)) no book? ((looking at another student)) ((T smiles)) so, who doesn't have a book, share with someone who has yeah? ((T laughs)) ok any idea what kind of sport is this? any idea? ah, page 18

40 S6: diving?

$\Gamma$ di wing, so, what kind of diving?

$\mathrm{S} 5 \cdot(\mathrm{XXX})((\mathrm{T}$ smiles $))$

$\Gamma$ : yes, this is free diving

The second type of smile was to promote a funny learning environment in the class. Their class lasted 2 hours and 10 minutes and the funny moments helped students feel more relaxed and willing to participate. The teacher's smile worked as an incentive to their participation as they also responded with a smile and showed interest in participating (based on observations and note taking during 
data collection). She was friendly and attentive with her learners in all classes observed and they reacted with their participation (but not their homework). We believe that such funny moments are going to be memorable for students as they were always linked to either the teacher's or the learners' real life situations.

\section{Interactive Moment 6 - Class 4 - funny environment}

At this moment of the class, the teacher does a listening activity with the students and checks the answers afterwards. The listening was a tool to introduce ED X ING endings of adjectives. Before this moment, she revised verb tenses and did a quiz about sports with students.

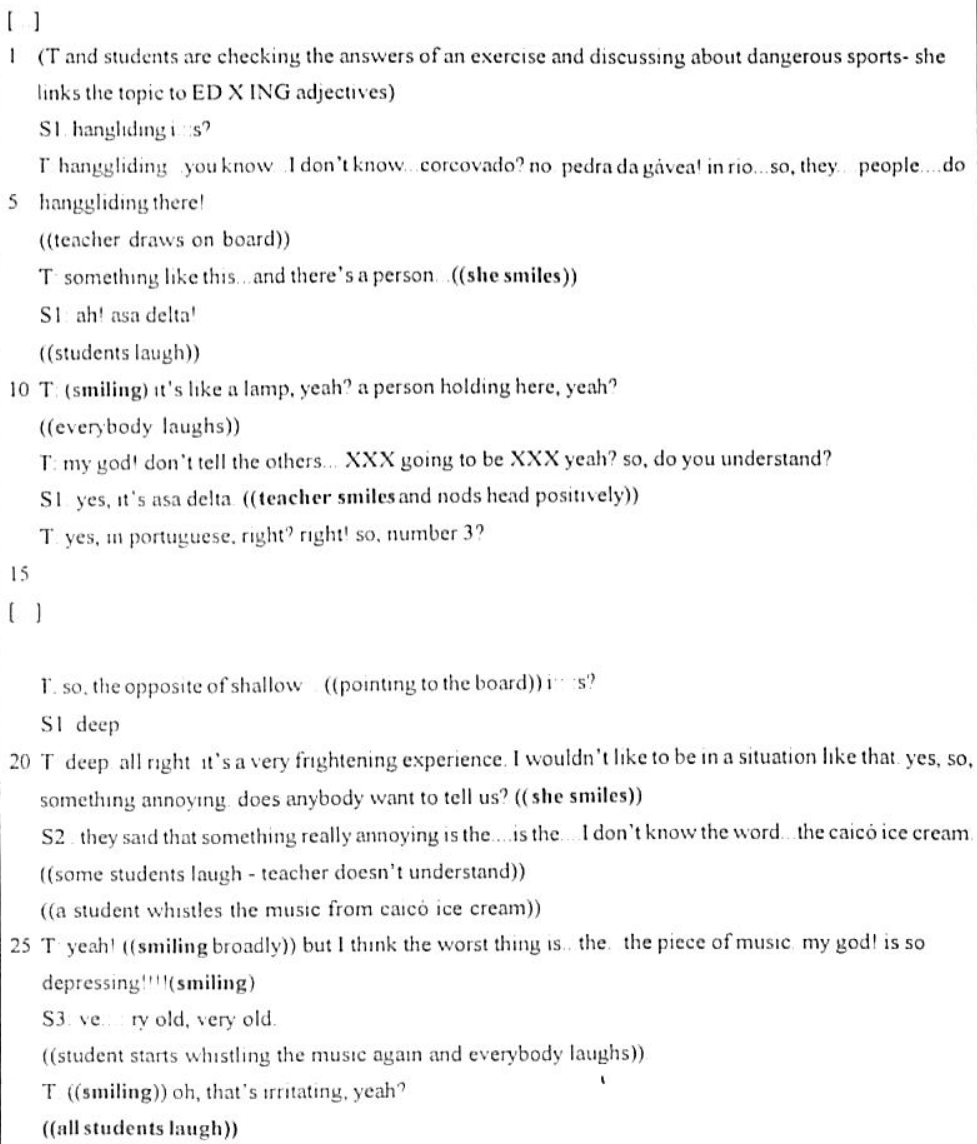

1 ( $\mathrm{T}$ and students are checking the answers of an exercise and discussing about dangerous sports- she links the topic to ED $\times$ ING adjectives)

Si hangliding i s?

$\mathrm{I}$ hanggliding youknow I don't know corcovado? no pedra da gaveal in rio... so, they people ...do 5 hanggliding there!

((teacher draws on board))

T something like this and there's a person .((she smiles))

S1 ah! asa delta'

((students laugh))

$10 \mathrm{~T}$ (smiling) it's like a lamp, yeah? a person holding here, yeah?

((everybody laughs))

$\mathrm{T}$. my god' don't tell the others.. XXX going to be XXX yeah? so, do you understand?

SI yes, it's asa delta ((teacher smiles and nods head posituvely))

T yes, in portuguese, right' right' so, number 3 ?

15

( )

r. so, the opposite of shallow ((pointung to the board)) i ' ' $s$ ?

SI deep

$20 \mathrm{~T}$ deep all right it's a very frightening experience. I wouldn't like to be in a situation like that yes, so, somethng annoymg does anybody want to tell us? (( she smiles))

S2. they sard that something really annoying is the ... is the. I don't know the word the caico ice cream ((some students laugh - teacher doesn't understand))

((a student whistles the music from carco ice cream))

$25 \mathrm{~T}$ yeah' ((

depressing!"'/(smiling)

S3. ve ry old, very old

((student starts whistling the music agan and everybody laughs))

T ((smiling)) oh, that's trritating, yeah?

((all students laugh)) 
A third and last type was to promote a convivial strategy or discourse so as to increase classroom interaction. In order to promote a convivial form of discourse in a classroom environment, according to Kramsch (1987), roles have to be negotiated between teacher and learners so that tasks are successfully achieved. There were moments of interaction, mainly student-student interaction, in which the teacher used the smile to show learners that she was happy they were doing what was expected from them. That caused the students a feeling of achievement and interest, contributing to their learning and language improvement. The convivial strategy, as it has been said before, is considered the ideal strategy when it comes to language teaching and learning in the classroom environment. It is a balance between the instructional strategy/discourse and the spontaneous strategy /discourse.

In the next extract, we show another IM where a convivial strategy is present, promoting a better interaction between the teacher and the learners. The class starts with the teachers telling the students that they are going to do a unit revision which will last about twenty minutes. She hands out copies of the test to the students and sets some time. When they finish, she checks answers and solves doubts. After that, she plays a game with students about articles. She divides them into two teams. They have to correct the sentences and throw a sticking ball on the board. The position the ball hits, indicates the number of points the team scores. 
I T: so, all these sentences have something in common

S1: articles

$\mathrm{T}$ : ar:....ticles! ((smiling))- all these sentences have problems with articles do you know how to use articles in english? (( smiles)) sometimes, yes? ((smiles))

5 S2: better sometimes than never

T: ((smiles)) yeah. well, basically, what articles... do we use in english?

S3: the.

$T$ : the.

S4: a/an

10 a or an... ((writing on board)) and? zero article you are going to see the use of this articles on page 192. please work in trio and decide who is going to explain what to each other

(students do the activity in trio, explaining the rules about articles (a,an,the) to one another))

((T smiles feeling pleased with students participation- after that, she asks students to do an exercise in the book and the teacher asks students to answer the sentences and choose another student to answer the

15 next sentence))

$\mathrm{T}$ : aline, another student

Aline his name is

$\mathrm{T}$ : ((smiles and nods her head))

Thiago thiago

20 Aline: thiago

((students finish correcting sentences with difficulty to remember everybody's names))

T: people, people . ((smiling)) you don't remember each other's names! I don't believe $1 t$ ! ok! revision! what's her name? (( and points to each student while everybody repeats classmates' names)). t-t-t ((norse with tongue)) bad, bad students (( smiling and playıng with students))

((students laugh))

This research tried to point out that the use of nonverbal language, together with verbal (they cannot be considered in isolation due to the fact that they depend on one another), was of great help when it comes to teaching a foreign language. It helped lower the affective filter between teacher and learners thus increasing interaction. When interaction is increased, students' learning is consequently improved through participation.

We believe that highly motivated students, as already mentioned by Krashen (1982), tend to do better in foreign language learning as well as self-confident students and classrooms which promote lowering students' anxiety. Students in this group showed to be motivated during class due to their participation and interest in the lessons. The smile worked as a tool to lessen students' anxiety, helping them feel more confident. As a consequence, lessons had high teacher-students and student-student interaction resulting in a livelier (sometimes funny) learning environment. 
The interactional process is extremely important to the human communication process. Nonverbal language is vital so that interaction is successful. It is an integrant part of verbal communication (RECTOR \& TRINTA, 1985). We observed that verbal and nonverbal language do not contradict one another but complete each other. They are part of the communicative process among teacher and learners, making the negotiation of meaning possible.

The ideas mentioned above are summarized and represented in the following graph:

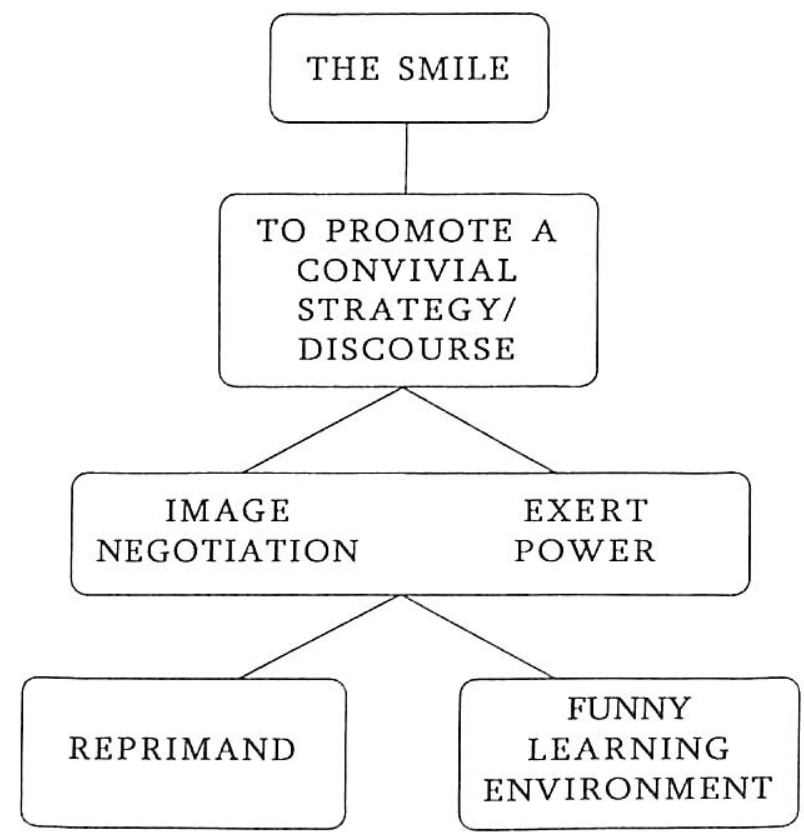

In the representation above, the smile is the element used by the teachers to promote a macro class environment which is called as a convivial strategy. It is through this convivial strategy that the teacher analyzed negotiated her image and exerted power when defining the roles between her and the students in class (she smiled and reprimanded at the same time). The smile was also used to promote a funny learning environment which increased students' participation and interaction, contributing to a more significant learning. 
It is important to point out that verbal and nonverbal language happen together and are used together due to the fact that they depend on one another, complement each other (SANTOS, 2004). The three types of smile described in this study also happen together. For instance: when the teacher is reprimanding the students, she is also saving her face and exerting power in the classroom. When a funny situation is taking place it is through a convivial strategy that everything happens. The same is true when the subject is language. It is hard to attempt to explain how language happens. Language is complex; it cannot be studied separately from the social context it happens or from situations in which the participants are interacting. This complexity to attempt to define language sent us to an interesting description about it - "Language is, according to an image of Wittgenstein himself, a nebulous, composed of multiple places, regions, sublanguages more or less similar among themselves, and it is in them and in their internal frontier transgressions that the philosopher should focus his attention" (COSTA, 2002, p.35). 


\section{References}

ALMEIDA FILHO, J. C. P. Dimensões Comunicativas no Ensino de Línguas. São Paulo: Pontes, 1993.

CARVALHO, Kate. The power of a smile. Sri Chinmoy Centre, New Zealand, 1999. IN: www.srichinmoycentre.org.

COSTA, C. Filosofia da Linguagem: filosofia passo-a-passo. Rio de Janeiro: Jorge Zaar Ed., 2002.

EKMAN, P. Emotions Revealed: recognizing faces and feelings to improve communication and emotional life. New York:

Henry Holt and Company, LCC, 2003.

FREITAS-MAGALHÃES. A Psicologia do sorriso humano. Porto: Edições UFP, 2004.

KENDOM, A. Research on Language and Social Interaction. Special Issue: Gesture and understanding in social interaction. Lawrence Erlbaum Associates Inc.: New Jersey, 1994.

Ekman, P. (and D. Friesen) 1969. The repertoire of non-verbal behaviour: categories, origins, usage and coding. IN: A. Kendon (ed.), Non-verbal communication, interaction, and gesture. Selections from Semiotica. The Hague, Mounton Publishers, 1981.

KINDE, John. Add power to your life to empower your relationships. In: www.humorpower.com, 1999. Posted 05.11.2005.

KRAMSCH, Claire. Context and Culture in Language Teaching. Oxford: Oxford University Press, 1993.

KRAMSCH, Claire. Interactive Discourse in Small and Large Groups. IN: W. Rivers (ed). Interactive Language Teaching. Cambridge: Cambridge University Press, 1987.

KRASHEN, S.D. Principles and Practice in Second Language Acquisition. Pergamon Press: Oxford, 1982

LEFFA, V. J.(org). A interação na aprendizagem das línguas. Pelotas: Educat, 2003.

LEFFA, V. J. Interação virtual versus interação face a face: o jogo das presenças e ausências. Trabalho apresentado no Congresso Internacional de Linguagem e Interação. São Leopoldo: Unisinos, agosto de 2005. 
MEHAN, H. Learning lessons:social organization in the classroom. Harvard University Press: Cambridge, 1978.

PEASE, A. \& PEASE, B. Desvendando os segredos da linguagem corporal. Sextante: Rio de Janeiro, 2005.

RECTOR, M. \& TRINTA, A. R. Comunicação do corpo. 4. Edição. São Paulo: Ed. Ática, 1999.

RECTOR, M. \& TRINTA, A. R. A Comunicação não-verbal: a gestualidade brasileira. Petrópolis: Vozes, 1985.

RIVERS, Wilga M. Interactive Language Teaching. Cambridge University Press, 1987.

SANTOS, M. F. O. A interação em sala de aula. 2. edição. Recife: Bagaço, 2004.

SANTOS, M. F. O. Considerações acerca dos elementos nãoverbais e verbais na comunicação humana. Cise em revista, ano I-1 - Fejal / Cesmac, 2004.

SANTOS, M. F. O. Os não verbais e verbais no discurso de sala de aula. (mimeo.), 2006.

SINCLAIR, J. M. R. \& COULTHARD, R. M. Towards an analysis of discourse. Oxford University Press: London, 1975.

TAVARES, R. R. O discurso interacional em sala de aula de língua estrangeira. Revista leitura n־28,29. Maceió: Edufal, 2004. p. 101-103.

TAVARES, R. R. A interação verbal no contexto pedagógico à luz da micro-análise etnográfica da interação. LEFFA, V. (org). In: Pesquisa em Lingüística Aplicada: temas e métodos. Pelotas: Educat, 2006.

TAVARES, R. R. A Negociação da Imagem em sala de aula de Língua Inglesa. Tese apresentada ao Programa de PósGraduação em Lingüística da Universidade Federal de Pernambuco para obtenção do Título de Doutor. Recife, 2001. 